\title{
PENGARUH PROSES REKRUTMEN DAN SELEKSI TERHADAP KINERJA KARYAWAN PADA PT. ANGKASA PURA I (PERSERO) BANDARA INTERNASIONAL SULTAN HASANUDDIN MAKASSAR
}

Oleh:

HAERUNNISA

INSTITUT BISNIS DAN KEUANGAN NITRO MAKASSAR

haerunnisa.sa28@gmail.com

\section{ABSTRAK}

Masalah pokok dalam penelitian ini adalah apakah proses rekrutmen dan seleksi berpengaruh terhadap kinerja karyawan pada PT. Angkasa Pura I (Persero) Bandara Internasional Sultan Hasanuddin Makassar, diantara proses rekrutmen dan seleksi yang manakah yang paling berpengaruh dominan terhadap kinerja karyawan pada PT.Angkasa Pura I (Persero) Bandara Internasional Sultan Hasanuddin Makassar.

Tujuan penelitian ini adalah untuk mengetahui pengaruh proses rekrutmen dan seleksi terhadap kinerja karyawan pada PT. Angkasa Pura I (Persero) bandara Internasional Sultan Hasanuddin Makassar.

II. PENDAHULUAN

Pengelolaan Sumber Daya Manusia (SDM) merupakan haal yang penting dalam pencapaian tujuan. Umumnya pimpinan perusahaan mengharapkan kinerja yang baik dari masing-masing karyawan dalam mengerjakan tugas-tugas yang diberikan oleh perusahaan. Perusahaan menyadari bahwa Sumber Daya Manusia (SDM) merupakan modal dasar dalam proses pembangunan perusahaan bahkan nasional, oleh karena itu kualitas SDM senantiasa harus dikembangkan dan diarahkan agar tercapainya tujuan yang telah ditetapkan oleh perusahaan. 
Sumber daya manusia kini makin berperan besar bagi kesuksesan suatu organisasi. Bnayak organisasi menyadari bahwa unsur manusia dalam suatu organisasi dapat memberikan keunggulan bersaing.mereka membuat sasaran, strategi, inovasi, dan mencapai tujuan organisasi. Oleh karena itu, sumber daya manusia merupakan salah satu unsur yang paling vital bagi organisasi. Manajemen sumber daya manusia berhubungan denga sistem rancangan formal dalam suatu organisasi untuk menentukan efektivitas dan efisiensi untuk mewujudkan sasaran suatu organisasi. Menurut Rivai, (2009 : 1) (di kutip dalam Daga, 2021)

Adapun aktivitas-aktivitas manajemen sumber daya manusia ini terdiri dari : perencanaan sumber daya manusia, pengadaan, pengarahan, pengembangan, pemeliharaan, dan pemberhentian. Hal ini ditujukan agar perusahaan dapat mengelola sumber daya manusia yang baik secara efektif dan efisien.

Salah satu aktivitas dalam pengelolaan SDM adalah rekrutmen dan seleksi. Rekrutmen adalah salah satu proses pengumpulan sejumlah pelamar yang memiliki kulifikasi yang sesuai dengan yang dibutuhkan perusahaan, untuk dipekerjakan di dalam perusahaan (Malhis, 2001). Adapun manfaat dari rekrutmen adalah memiliki fungsi sebagai "the Right Man on The Right Place", dimana hal ini menjadi pegangan bagi para manager dalam menempatkan tenaga kerja yang ada di perusahaannya.

Rekrutmen merupakan serangkaian aktivitas untuk mencari dan me,ikat pelamar kerja dengan motivasi, kemampuan, keahlian dan pengetahuan yang diperlukan guna menutupi kekurangan yang diidentifikasi dalam perencanaan kepegawaian. Sedangkan seleksi merupakan proses pemilihan dari sekelompok pelamar atau orang-orang yang memenuhi ktiteria untuk menempati posisi yang tersedia berdasarkan kondisi yang ada pada perusahaan.

PT. Angkasa Pura I (Persero) merupakan peurusahaan yang bergerak di bidang jasa pengelolaan bandara, dimana bandara Internasional Sultan Hasanuddin merupakan faktor pengungkit untuk keunggulan bersaing PT. Angkasa Pura I (Persero), sehingga pengembangan Kompetensi Suber 
Daya Manusia merupakan salah satu faktor kunci keberhasilan untuk pencapaian visi dan misi PT. Angkasa Pura I (Persero). Sejalan dengan visi, misi, dan strategi perusahaan untuk menjadi perusahaan kelas dunia di bidang jasa kebandaraudaraan, perlu diterapkan upaya yang lebih fokus dalam pengembangan SDM secara konsisten dan terus menerus.

Pengelolaan sumber daya manusia sangat diperlukan untuk efektivitas sumber daya manusia dalam suatu organisasi. Tujuan dari hal tersebut adalah untuk memberikan kepada organisasi satuan kerja yang efektif untuk mencapai tujuan studi tentang manajemen perusahaan bagaimana seharusnya perusahaan dapat mengembangkan, menggunakan dan memelihara karyawan dalam kualitas dan kuantitas yang tetap.

Oleh karena itu pihak manajemen perusahaan harus mampu memahami bagaimana cara terbaik dalam mengelola karyawan yang berasal dari latar belakang, keahlian, dan kemampuan yang berbeda-beda sehingga karyawan dapat bekerja sesuai dengan keahlian dan jenis pekerjaan yang diberikan.

Penyusutan pegawai yang terjadi biasanya karena adanya pegawai yang memasuki masa pensiun, meninggal dunia atau dikeluarkan dari institusi karena melakukan pelanggaran tata tertib disiplin yang telah ditetapkan oleh PT. Angkasa Pura I (Persero). Oleh karena itu pegawai baru yang akan menggantikannya akan memiliki masa kerja yang berbedabeda. Rekrutmen juga dapat dilakukan untuk menambah begawai baru kedalam suatu satuankerja yang kegiatannya menuntut aktivitas yang tinggi. Dalam proses retrutmen juga memerlukan adanya proses yang efektif, hal ini dilakukan untuk melakukan pemerataan pegawai sehingga kekuatan SDM yang dimiliki menjadi lebih seimbang.

Sistem perekrutan dan seleksi di dalam PT. Angkasa Pura I (Persero) Bandara Sultan Hasanuddin Makassar tidak hanya menghasilkan pegawai yang statusnya sebagai pegawai tetap, namun meningkat efektifitasan perusahaan maka PT. Angkasa Pura I (Persero) Bandara Internasional Sultan Hasanuddin Makassar juga menggunakan tenaga kerja yang berasal dari outsourching. 
Kegagalan dalam melakukan sistem perekrutan tenaga kerja akan berdampak pada proses pencapaian tujuan perusahaan. Dimana kinerja dari PT. Angkasa I pura (Persero) Bandara Sultan Hasanuddin Makassar tidak hanya melayani arus lalu lintas udara, namun juga mampu menjaga kesinambungan dam memberikan pelayanan yang baik bagi konsumen.

Mengingat sangat pentingnya proses rekrutmen dan seleksi bagi perusahaan. Diharapkan dengan adanya proses rekrutmen dan seleksi yang baik dan efektif akan berdampak pada perkembangan perusahaan kedepannya untuk memperoleh sumber daya yang berkualitas di PT. Angkasa Pura I (Persero) Bandara Internasional Sultan Hasanuddin Makassar.

\section{TINJAUAN PUSTAKA}

1. Pengertian Manajemen dan Sumber Daya Manusia

a. Pengertian Manajemen

Sebelum mengemukakan beberapa pendapat mengenai apa yang dimaksud dengan manajemen sumber daya manusia, maka perlu dijelaskan terlebih dahulu mengenai arti manajemen itu sendiri, karena manajemen sumber daya manusia merupakan bagian dari fungsi manajemen itu sendiri.

Menurut Hasibuan (2008), manajemen adalah ilmu dan seni mengatur proses pemanfaatan sumber daya manusia dan sumbersumber daya lainnya secara efektif dan efisien untuk mencapai suatu tujuan tertentu. Pengertian ini menjelaskan bahwa manajemen merupakan suatu ilmu dan seni dimana dalam pelaksanaannya seorang manajer perlu mencari dalam memberdayakan sumber daya yang dimiliki secara efektif dan efisien guna mencapai tujuan perusahaan.

Sedangkan menurut Samsudin (2010) mengemukakan bahwa manajemen adalah bekerja dengan orang-orang untuk mencapai tujuan organisasi dengan pelaksanaan perencanaan (planning), 
pengorganisasian (oeganazing), penyusunan personalia atau kepegawaian (staffing), pengarahan dan kepemimpinan (leading), dan pengawasan (cintrolling). Sedangkan menurut G. R Terry (dalam Samsudin 2010) mengemukakan manajemen adalah suatu proses yang khas, yang terdiri dari tindakan perencanaan, pengorganisasian, pergerakan, dan pengendalian yang dilakukan untuk menetukan serta mencapai sasaran-sasaran yang telah ditentukan melalui pemanfaatan sumber daya manusia dan sumber daya lainnya.

b. Pengertian Manjemen Sumber Daya Manusia

Sumber daya manusia dalam organisasi merupakan human capital, karena sumber daya manusia memberikan kontribusi terhadap prifibilitas. Seringkali juga disebut sebagai modal intelektual (intelectual capital), karena kemampuan memberikan ide-ide cemerlang dalam pengembangan organisasi. Manajemen sumber daya manusia merupakan konsep luas tentang filosofi, kebijakan, prosedur dan praktek yang digunakan untuk mengelola individu atau manusia melalui organisasi. Penggunaan konsep dan sistem sumber daya manusia adalah kontrol secara sistematis dari proses jaringan fundamental organisasi yang mempengaruhi dan melibatkan semua individu dalam organisasi, termasuk proses perencanaan sumber daya manusia, desain pekerjaan, susunan kepegawaian, pelatihan dan pengembangan, representasi dan perlindungan tenaga kerja, serta pengembangan organisasi. Untuk mengendalikan dan mengatur proses tersebut, maka sistem hatus direncanakan, dikembangkan dan diimplementasikan oleh manajemen puncak.

Manajemen memang dapat mempunyai pengertian lebih luas dari pada itu, tetapi definisi di atas memberikan kenyataan bahwa kita terutama mengelola sumber daya manusia bukan materil atau finansial. Di lain pihak, manajemen mencakup fungsi-fungsi perencanaan (penetapan apa yang akan dilakukan), pengorganisasian (perancangan dan penugasan kelompok kerja), penyusunan personalia (penarikan, seleksi, pengembangan, pemberian kompensasi dan penilaian 
produktivitas kerja). Pengarahan (motivasi, kepemimpinan integrasi, dan pengelolaan konflik) dan pengawasan. Lalu apa definisi sumbernya manusia? Manajemen sumber daya manusia mempunyai kekhusunan dibandingkan dengan manajemen secara umum, karena yang di "manage" adalah manusia, sehingga keberhasilan atau kegagalan manajemen sumber daya manusia ini mempunyai dampak yang sangat luas.

Rachmawati (2008 : 3) memberikan definisi manajemen sumber daya manusia sebagai berikut:

Manajemen sumber daya manusia merupakan suatu proses perencanaan, pengorganisasia, pengarahan dan pengawasan kegiatankegiatan pengadaan, pengembangan, pemberian kompensasi, pengintegrasian, pemeliharaan dan pelepasan sumber daya manusia agar tercapai berbagai tujuan individu, organisasi dan masyarakat. Selanjutnya, Yuniarsih dan Suwatno (2008: 1) mengemukakan bahwa : "Manajemen sumber daya manusia merupakan bagian dari ilmu manajemen yang memfokuskan perhatiannya pada pengaturan peranan sumber daya manusia dalam kegiatan suatu organisasi".Hal senada dikemukakan pula oleh Rivai (2009: 6) bahwa:

Manajemen sumber daya manusia merupakan salah satu bidang dari manajemen yang meliputi segi-segi perencanaan, pengorganisasian, pelaksanaan dan pengendalian. Karena sumber daya manusia dianggap semakin penting perannya dalam pencapaian tujuan organisasi, maka berbagai pengalaman dan hal penelitian dalam bidang sumber daya manusia dikumpulkan secara sistematis. Istilah manajemen mempunyai arti sebagai kumpulan pengetahuan tentang bagaimana seharusnya mengelola sumber daya manusia. Begitu pula halnya dengan Sofyandi (2008: 6) manajemen sumber daya manusia didefinisikan sebagai berikut:

Manajemen sumber daya manusia merupakan suatu strategi dan menerapkan fungsi-fungsi manajemen yaitu planning, organizing, leading, dan controlling, dalam setiap aktivitas/fungsi operasional 
sumber daya manusia SDM mulai dari proses penarikan, seleksi, pelatihan dan pengembangan, penempatan yang melipuyi promosi, demosi dan tranfer, industrial, hingga pemutusan hubungan kerja, yang ditujukan bagi peningkatan kontribusi produktif dari sumber daya manusia organisasi terhadap pencapaian tujuan organisasi secara lebih efektif dan efisien.

Selanjutnya menurut Mondy (2008 : 4) mengemukakan bahwa

Manajemen sumber daya manusia adalah pemanfaatan sejumlah individu untuk mencapai tujuan-tujuan organisasi. Konsekuensinya, para manajer disetiap tingkat harus melibatkan diri mereka dengan manajemen sumber daya manusia. Pada dasarnya, semua manajer membuat segala sesuatunya terselesaikan melalui upaya-upaya ;ain, ini memerlukan sumbe daya manusia yang efektif.

Manajemen sumber daya manusia mempunyai peranan yang penting yang dimainkan oleh sumber daya manusia dalam suatu organisasi yang menuntut pengelolaan sumber daya manusia yang semakin efektif sejalan dengan perkembangan ilmu pengetahuan dan profesionalisme dalam bidang manajemen personalia dan manajemen sumber daya manusia dalam suatu organisasi guna mencapai tujuan bisnis atau sebagai suatu mekanisme pengintegrasian antara kebijakan-kebijakan perusahaan dengan penerapannya dalam mengelola sumber daya manusia dan kaitannya dengan strategi organisasi.

Relevansi dan pentingnya manajemen sumber daya manusia tidak terlepas dari berbagai perkembangan dan kemajuan yang dicapai di bidang ilmu pengetahuan dan teknologi. Dampak dari berbagai kemajuan tersebut dapat bersifat positif dan juga bisa negatif.

\section{Rekrutmen}

a. Pengertian Rekrutmen

Rekrutmen merupakan suatu keputusan perencanaan 
manajemen sumber daya manusia mengenai jumlah karyawan yang dibutuhkan, kapan diperlukan, serta kriteria apa saja yang diperlukan dalam suatu organisasi.

Rekrutmen pada dasarnya merupakan usaha untuk mengisi jabatan atau pekerjaan yang kosong di lingkungan suatu organisasi atau perusahaan, untuk itu terdapat dua sumber-sumber tenaga kerja yakni sumber dari luar (eksternal) organisasi atau dari dalam (internal) organisasi.

Penarikan (rekrutmen) pegawai merupakan suatu proses atau tindakan yang dilakukan oleh organisasi untuk mendapatkan tambahan pegawai melalui beberapa tahapan yang mencakup identifikasi dan evaluasi sumber-sumber penarikan tenaga kerja, menentukan kebutuhan tenaga kerja, proses seleksi, penempatan, dan orientasi tenaga kerja. Penarikan pegawai bertujuan menyediakan pegawai yang cukup agar manajer dapat memilih karyawan yang memenuhi kualifikasi yang mereka perluan (Malthis : 2001).

Rekrutmen yang efektif memerlukan tersedianya informasi yang akurat dan berkesinambungan mengenai jumlah dan kualifikasi individu yang diperlukan untuk melaksanakan berbagai pekerjaan dalam organisasi.

Aktivitas rekrutmen akan menyisihkan pelamar yang kurang tepat dan memfokuskan upayanya pada calon yang akan dipanggil kembali. Aktivitas rekrutmen dapat membangun opini publik yang menguntungkan dengan cara mempengaruhi sikap para pelamar sedemikian rupa terlepas mereka diangkat atau tidak.

Husibuan (2008) menyatakan bahwa rekrutmen merupakan usaha mencari dan mempengaruhi tenaga kerja, agar mau melemar lowongan pekerjaan yang ada dalam suatu organisasi. Sedangkan menurut Simamora (2004) merupakan serangkaian aktivitas mencari dan memikat pelamar kerja dengan motivasi, kemampuan, keahlian, dan pengetahuan yang diperlukan untuk menutupi kekurangan yang 
diidentifikasi dalam perencanaan kepegawaian. Aktivitas rekrutmen dimulai pada saat calon mulai cari, dan berkhir pada saat lamaran mereka diserahkan.

Handoko (2008) menjelaskan bahwa rekrutmen merupakan proses pencarian dan "pemikatan" para calon karyawan (pelamar) yang mampu untuk melamar segabai karyawan. Lebih jauh lagi, Rivai (2009) menjelaskan rekrutmensebagai suatu rangkaian kegiatan yang dimulai ketika sebuah perusahaan memerlukan tenaga kerja dan membuka lowongan sampai mendapatkan calon yang diinginkan atau memenuhi kualifikasi sesuai dengan jabatan atau lowongan yang ada.

Rekrutmen merupakan masalah yang penting bagi perusahaan dalam hal pengadaan tenaga kerja. Jika suatu rekrutmen berhasil dengan kata lain banyak pelamar yang memasukkan lamarannya, maka peluang perusahaan untuk mendapatkan karyawan yang terbaik akan menjadi semakin terbuka lebar, karena perusahaan akan memiliki banyak pilihan yang terbaik dari para pelamar yang ada.

\section{b. Sikap Dalam Rekrutmen}

Nawawi (2008) mengemukakan terdapat 4 (empat) sikap yang berbeda di lingkungan organisasi/perusahaan dalam melakukan rekrutmen. Keempat sikap tersebut adalah:

1. Sikap pasif tanpa diskriminasi, sikap ini merupakan sikap para eksekutif di lingkungan organisasi/perusahaan untuk meniadakan perbedaan dan memberlakukan secara sama dalam mengangkat, menggaji dan memberikan promosi bagi para calon dan para pekerja.

2. Rektutmen berdasarkan perbedaan, rekrutmen ini dilakukan secara aktif untuk mengelompokkan para pelamar, dengan hanya menerima kelompok tertentu.

3. Rekrutmen berdasarkan prioritas, rekrutmen ini dilakukan dengan mendahulukan atau memprioritaskan kelompok tertentu. 
4. Rekrutmen dengan benjatahan, rekrutmen ini dilakukan dengan menetapkan jatah untuk kelompok tertentu.

Berdasarkan keempat sikap tersebut, maka keputusan dalam rekrutmen dan pengaturan staf sebaiknya dilakukan berdasarkan kasus masing-masing. Dengan demikian ras dan jenis kelamin yang seringkali menjadi masalah, dapat dijadikan salah satu faktor saja dalam pengambilan keputusan untuk menerima atau menolak calon pelamar. Keputusan harus berdasarkan pada kombinasi semua faktor yang ada, danga harus mengutamakan hasil skor (nilai) tes sebagai usaha dalam memprediksi kemampuan calon sebelum diterima.

\section{c. Proses Rekrutmen}

1. Job Analysis (Analisis Jabatan)

Analisis jabatan merupakan prosedur untuk menentukan tanggung jawab dan persyaratan, keterampilan dari sebuah pekerjaan dan jenis orang yang dipekerjakan.

2. Job Description (Uraian Jabatan)

Menurut Yoder (dalam Moekijat, 2010) mengatakan bahwa uraian jabatan adalah mengihktisarkan fakta-fakta yang diberikan oleh analisis jabatan dalam susunan yang sistematis. Uraian jabatan merupakan garis-garis besar yang ditulis dan dimaksudkan untuk memberikan keterangan tentang fakta-fakta yang penting dari jabtan yang diperlukan.

3. Job Specification (Persyaratan Jabatan)

Persyaratan pekerjaan adalah catatan mengenai syarat-syarat orang yang minimum harus dimiliki untuk menyelesaiakan suatu pekerjaan dengan baik (Moekijat : 2010)

4. Job Evaluation (Penilaian Jabatan) 
Menurut Moekijat (2010) penilaian jabatan adalah kegiatan yang dilakukan guna membandingkan nilai dari suatu jabatan dengan nilai dari jabatan dengan jabatan lainnya.

5. Job Classification (Penggolongan Jabatan)

Penggolongan jabatan adalah pengelompokan jabatan-jabatan yang memiliki nilai yang sama (Moekijat, 2010).

\section{d. Penetuan Dasar Rekrutmen}

Menurut Hasibuan (2008), dasar penarikan calon karyawan harus ditetapkan lebih dahulu supaya para pelamar yang akan memasukkan lamarannya sesuai dengan pekerjaan atau jabatan yang diminatinya. Dasar penarikan harus berpedoman pada spresifikasi pekerjaan yang telah ditentukan untuk menduduki jabatan tersebut. Job Specification harus diuraikan secara terperinci dan jelas agar para pelamar mengetahui kualifikasi yang dituntut oleh lowongan kerja tersebu. Jika spesifikasi pekerjaan dijadikan dasar dan pedoman penarikan, maka karyawan yang diterima akan semuai denga uraian pekerjaan dari jabatan yang diperlukan oleh perusahaan.

\section{e. Penentuan Sumber-Sumber Rekrutmen}

Setelah diketahui spesifikasi jabatan atau pekerjaan karyawan yang diperlukan, maka harus ditentukan sumber-sumber penarikan calon karyawan. Sumber penarikan calon karyawan bisa berasal dari internal dan eksternal perusahaan.

\section{A. Sumber Internal}

Sumber internal menurut Hasibuan (2008) adalah karyawan yang akan mengisi lowongan kerja yang diambil dari dalam perusahaan tersebut. Hal ini dapat dilakukan dengan cara melakukan mutasi atau memindahkan karyawan yang memenuhi spesifikasi jabatan atau pekerjaan tersebut. Pemindahan karyawan bersifat vertical 
(promosi atau demosi) maupun bersifat horizontal. Jika masih ada karyawan yang dapat memenuhi spesifikasi pekerjaan, sebaiknya perusahaan mengambil dari dalam perusahaan khususnya untuk jabatan manajerial. Hal ini sangat penting untuk memberikan kesempatan promosi bagi karyawan yang ada.

Adapun kebaikan dari sumber internal yaitu:

1. Tidak terlalu mahal

2. Dapat memelihara loyalitas dan mendorong motivikasi karyawan yang ada.

3. Karyawan telah terbiasa denga suasana dan budaya perusahaan.

Sedangkan kelemahan dari sumber internal yaitu:

1. Pembatan terhadap bakat-bakat

2. Mengurangi peluang.

3. Dapat meningkatkan perasaan puas diri.

Adapun sumber-sumber internal antara lain melalui:

1. Penawaran terbuka untuk suatu jabatan (Job Posting Program).

Rekrutmen terbuka ini merupakan sistem mencari pekerja yang memiliki kemampuan tinggi untu mengisi jabatan yang kosong dengan memberikan kesempatan kepada semua karyawan yang berminat.

2. Perbantuan pekerja (Departing Employees)

Rekrutmen ini dapat dilakukan melalui perbantuan pekerja untuk suatu jabatan dari unit kerja lain.

B. Sumber Eksternal

Menurut Hasibuan (2008), sumber eksternal adalah karyawan yang akan mengisi jabatan yang lowong yang dilakukan perusahaan dari 
sumber-sumber yang berasal dari luar perusahaan. Sumber-sumber eksternal berasal dari:

1. Kantor penempatan tenaga kerja

2. Lembaga-lembaga pendidikan

3. Reverensi karyawan atau rekan

4. Serikat-serikat buruh

5. Pencangkokan dari perusahaan lain

6. Nepotisme atau leasing

7. Pasar tenaga kerja dengan memasang iklan pada media massa

8. Sumber-sumber lainnya.

\section{Pengertian Seleksi}

Seleksi merupakan bagian materi dari operasional manajemen sumber daya manusia yaitu pengadaan (procurement), sedangkan pengadaan itu sendiri teridiri dari: perencanaan, perekrutan, seleksi, penetapan, dan produksi. Proses seleksi merupakan tahap-tahap khusus yang digunakan untuk memutuskan pelamar mana yang akan diterima. Proses tersebut dimulai ketika pelamar kerja dan diakhiri dengan keputusan penerimaan. Proses seleksi merupakan pengambilang keputusan bagi calon pelamar untuk diterima atau tidak.

Menurut Simamora (2004), seleksi merupakan proses pemilihan dan sekelompok pelamar yang paling memenuhi kriteria seleksi untuk posisi yang tersedia dalam perusahaan sedangkan menurut Teguh (2009) menjelaskan bahwa seleksi adalah proses yang terdiri dari berbagai langkah yang spesifik dari kelompok pelamar yang paling cocok dan memenuhi syarat untuk jabatan tertentu.

Ada tiga hal yang menyebabkan seleksi menjadi hal yang penting, yaitu:

1. Kinerja pana manajer senantiasa tergantung pasa sebagian kinerja 
bawahannya

2. Seleksi yang efektif penting karena biaya perekrutan yang dikeluarkan oleh perusahaan dalam pengankatan pegawai tidak sedikit

3. Seleksi yang baik itu penting karena implikasi hukum dari pelaksanaannya secara serampangan.

a. Kriteria dan Teknik Seleksi

Perusahaan tentu akan mengharapkan para pelamar yang datang memiliki prestasi yang memuaskan dalam pekerjaannya. Kriteria seleksi menurut Simamora (2004) pada umumnya dapat dirangkum dalam beberapa kategori:

1. Pendidikan

2. Pengalaman kerja

3. Kondisi fisik

4. Kepribadian

Sebelum perusahaan memutuskan karakteristik yang akan disekesi, maka perusahaan sebaiknya memiliki kriteria sukses yang telah ditetapkan sebelumnya untuk menentukan cara untuk memprediksi pelamar mana yang mencapai tingkat yang diharapkan.

Adapun bebrapa teknik seleksi antara lain:

1. Interview

2. Tes psikologi

3. Tes mengenai hal-hal yang berhubungan dengan pekerjaan

4. Pusat pelatihan

5. Biodata

6. Referensi 
7. Grafologi (ilmu yang berkenaan denga tulisan tangan)

Sedangkan langkah-langkah dalam seleksi yaitu:

1. Seleksi surat-surat lamaran

2. Pengisian blanko lamaran

3. Pemeriksaan referensi

4. Wawancara pendahuluan

5. Tes penerimaan

6. Tes psikologi

7. Tes kesehatan

8. Wawancara akhir atasan langsung

9. Memutuskan diterima atau ditolak

b. Prinsip Proses Seleksi

Proses pengambilan keputusan pengangkata yang baik akan sangat tergantung pada dua prinsip dasar proses seleksi, yaitu:

1. Perilaku dimasa lalu yang merupakan predictor terbaik atas perilaku dimasa yang akan datang

2. Perusahaan harus menghimpun data yang handal sebanyak mungkin yang dapat dimanfaatkan untuk menyeleksi pelamar yang terbaik

c. Dasar Seleksi

Dasar seleksi merupakan penerimaan pegawai baru yang hendaknya berpedomana pada dasar tertentu yang telah digariskan secara internal maunpun eksternal oleh perusahaan. Menurut Hasibuan (2008) dasardasar tersebut antara lain:

1. Kebijakan perubahan atau tenaga kerja oleh pemerintah

2. Jabatan 


\section{Ekonomi rasional}

4. Etika sosial

d. Penetapan Jumlah pegawai

Hasibuan (2008) berpendapat bahwa penetapan jumlah pegawai yang bai, harus diperhitungkan denga cermat agar karyawan yang diterima tetap adn sesuai dengan folume pekerjaan. Untuk menetukan jumlah pegawai tersebut, dapat dilakukan dengan metode ilmiah dan metode non ilmiah.

1. Metode ilmiah

Jumlah karyawan yang akan diterima benar-benar melalui perhitungan analisis beban kerja standar serta prestasi kerja

2. Metode non ilmiah

Jumlah karyawan yang akan diterima hanya didasarkan atas perkiraan saja bukan dari standar volume kerja dab beban kerja

\section{e. Cara Seleksi}

Adapun cara seleksi yang digunakan oleh perusahaan maupun organisasi dalam penerimaan karyawan baru dewasa ini dikenal dengan dua cara yaitu:

1. Non ilmiah

Yaitu seleksi yang dilaksanakan tidak didasarkan atas ktiteria stndar, atau spesifikasi kebutuhan nyata suatu pekerjaan atau jabatan. Akan tetapi hanya didasarkan pada perkiraan dan pengalaman saja. Selesi dalam hal ini dilakukan tidak berpedoman pada uraian spesifikasi pekerjaan dari jabatan yang akan diisi. Unsur-unsur yang diseleksi biasanya meliputi hal-hal seprti:

a) Surat lamaran bermaterai atau tidak

b) Ijazah sekolah dan daftar nilainya

c) Surat keterangan kerja dan pengalaman 
d) Referensi atau rekomendasi dari pihak yang dapat dipercaya

e) Wawancara langsung dengan yang bersangkutan

f) Penampilan dan keadaan fisik pelamar

g) Keturanan dari pelamar

h) Tulisan tanga pelamar

2. Ilmiah

Metode ilmiah merupakan metode seleksi yang didasarkan pada spesifikasi pekerjaan dan kebutuhan nyata yang akan diisi, serta berpedoman pada kriteria dan standar-standar tertentu. Seleksi ilimiah mengacu pada hal-hal antara lain:

a) Metode kerja yang sistematis

b) Berorientasi pada kebutuhan riil karyawan

c) Berorientasi kepada prestasi kerja

d) Berpedoman pada undang-undang perburuhan

e) Berdasarkan kepada analisa jabatan dan ilmu sosial lainnya

\section{f. Faktor-faktor yang Mempengaruhi Proses Seleksi}

Simamora (2004) menjelaskan proses seleksi dibuat dan disesuaikan untuk memenuhi kebutahan kepegawaian suatu perusahaan atau organisasi. Ketelitian dari proses seleksi bergantung pada beberapa faktor, yaitu:

1. Konsekuensi seleksi yang salah diperhitungkan

2. Yang mampu mempengaruhi proses seleksi adalah kebijkan perusahaan dan sikap dari manajemen

3. Waktu yang tersedia untuk mengembil keputusan seleksi yang cukup lama 
4. Pendekatan seleksi yang berbeda umumnya digunakan untuk mengisi posisi-posisi dijenjang yang berbeda dalam perusahaan

5. Faktor ekonomi dimana individu akan dipilih baik swasta, pemerintah atau nirlaba juga dapat mempengaruhi proses seleksi

\section{g. Kendala-Kendala Seleksi}

Pelaksanaan seleksi selalu memiliki kendala walaupun telah direncankana secara cermat. Hal ini terjadi karena yang akan diseleksi adalah manusia yang memiliki pikiran, dinamika, dan harga diri. Kendala-kendala tersebut antara lain:

1. Tolak ukur

2. Penyeleksi

3. Pelamar

h. Tujuan Seleksi

Seleksi merupakan fungsi yang penting karena berbagai macam keahlian yang dibutukan oleh organisasi untuk mencapai tujuannya diperoleh dari proses seleksi. Proses seleksi akan melibatkan proses menduga yang terbaik (best-guest) dari pelamar yang ada. Seleksi penerimaan pegawai baru bertujuan untuk mendapatkan hal-hal berikut:

1. Karyawan yang memiliki potensi

2. Karyawan yang disiplin dan jujur

3. Karyawan yang sesuai dengan tugas dan keahlian yang diperlukan

4. Karyawan yang terampil

5. Karyawan yang kreatif dan dinamis

6. Karyawan yang loyal

7. Mengurangi turnover karyawan

8. Karyawan yang sesuai denga budaya organisasi 
9. Karyawan yang dapat bekerja sama didalam perusahaan

10. Karyawan yang mudah dikembangkan dari masa yang akan datang.

\section{METODE PENELITIAN}

POPULASI DAN SAMPEL

Pada penelitian ini, penulis menjadikan karyawan dari PT. Angkasa Pura I (Persero) Bandara Internasional Sultan Hasanuddin Makassar sebagai populasi, yang sampai tahun 2009 totalnya berjumlah 3.868 orang. Kemudian akan digunakan metode Simple Random Sampling, yaitu metode penarikan sampel dimana setiap anggota populasi mempunyai peluang yang sama untuk dipilih menjadi sampel.

Adapun jumlah sampel tersebut diperoleh dari perhitungan yang dikemukakan oleh Slovin dalam Husain (2003 : 146) sebagai berikut :

$$
\mathrm{n}=\frac{\mathrm{N}}{1+\mathrm{Ne}^{2}}
$$

Dimana :

$\mathrm{n} \quad=$ Ukuran sampel

$\mathrm{N} \quad=$ ukuran populasi yaitu jumlah karyawan PT. Angkasa Pura I (Persero) Bandara Internasional Sultan Hasanuddin Makassar

e $\quad=$ persen kelonggaran ketidaktelitian karena kesalahan pengambilan sampel yang masih dapat dirolerir atau diinginkan, sebanyak $10 \%$.

\section{KESIMPULAN}

Rekrutmen merupakan suatu keputusan perencanaan manajemen sumber daya manusia mengenai jumlah karyawan yang dibutuhkan, kapan diperlukan, serta kriteria apa saja yang diperlukan dalam suatu organisasi.

Faktor-faktor yang Mempengaruhi Proses Seleksi 
1. Konsekuensi seleksi yang salah diperhitungkan

2. Yang mampu mempengaruhi proses seleksi adalah kebijkan perusahaan dan sikap dari manajemen

3. Waktu yang tersedia untuk mengembil keputusan seleksi yang cukup lama

4. Pendekatan seleksi yang berbeda umumnya digunakan untuk mengisi posisi-posisi dijenjang yang berbeda dalam perusahaan

5. Faktor ekonomi dimana individu akan dipilih baik swasta, pemerintah atau nirlaba juga dapat mempengaruhi proses seleksi

\section{DAFTAR PUSTAKA}

Andhika Ery, 2011, Pengaruh Perekrutan Terhadap Kinerja Karyawan pada PT Perkebunan Nusantara III (Persero) Medan.

Daga, R. (2021). ANALISIS KOMPETENSI KARYAWAN BERDASARKAN GENDER PADA PT. BANK RAKYAT INDONESIA (PERSERO), Tbk CABANG SOPPENG.

Fitri Yunila Sari, 2010, Pengaruh Sistem Rekrutmen terhadap kinerja Karyawan Outsourcing pada PT. Personel Alih Daya Wilayah Sombagut

Hasibuan, Malayu, SP. 2008, Manajemen Sumber Daya Manusia, edisi revisi, Cetakan ketujuh,Penerbit : Bumi Aksara, Jakarta

Handoko T. Hani, 2008, Manajemen Personalia dan Sumber Daya Manusia, edisi kedua, Penerbit: BPFE, Yogyakarta Husein, Umar 2003, Metode Riset Perilaku Konsumen Jasa, 
cetakan pertama, Ghalia Indonesia, Jakarta.

Mangkunegara, Anwar Prabu, 2008, Manajemen Sumber Daya

Manusia Perusahaan, cetakan pertama, Penerbit: Remaja Rosdakarya, Bandung

Malthis, Robert, L dan John H. Jackson, 2001, Human Resource Management (Manajemen Sumber Daya Manusia), Edisi Sepuluh, Terjemahan : Diana Angelica, Penerbit : Salemba Empat, Jakarta.

Moekijat, 2010, Manajemen Sumber Daya Manusia, cetakan kesembilan, Penerbit :Mandar Maju, Bandung

Nawawi, Hadari, 2008, Manajemen Sumber Daya Manusia Untuk Bisnis yang Kompetitif,cetakan keempat, Penerbit : Gadjah Mada University Press, Yogyakarta

Mondy R. Wayne, 2008, Manajemen Sumber Daya Manusia, edisi kesepuluh, jilid 1, Penerbit : Erlangga, Jakarta

Rivai, Veithzal, 2009, Manajemen Sumber Daya Manusia untuk Perusahaan, edisi kedua, Penerbit : Rajawali Pers, Jakarta

Riduan dan Akdon, 2007, Rumus dan Data dalam Analisis Statistika,cetakan kedua, Penerbit : Alfabeta, Bandung

Rachmawati Ike Kusdyah, 2008, Manajemen Sumber Daya Manusia, edisi pertama, cetakan pertama, Penerbit : Andi 
Offset, Jakarta

Riduwan, 2009, Metode dan tehnik menyusun tesis, Penerbit :

Alfabeta, Bandung

Simamora, Henry, 2004, Manajemen Sumber Daya Manusia, edisi ketiga, cetakan pertama, Penerbit : YKPN, Yogyakarta

Sofyandi Herman, 2008, Manajemen Sumber Daya Manusia, edisi pertama, cetakan pertama, Penerbit : Graha Ilmu, Jakarta Sugiyono, 2009, Metode Penelitian Administrasi : dilengkapi dengan Metode R \& D, Penerbit : Alfabeta, Bandung Sulistiyani Ambar Teguh dan Rosidah, 2009, Manajemen Sumber Daya Mansusia, Konsep Teori dan Pengembangan Dalam Konteks Organisasi Publik, edisi kedua, cetakan pertama, Penerbit: Graha IImu, Jakarta

Samsudin, H, Sadeli, 2010, Manajemen Sumber Daya Manusia, Penerbit Pustaka Setia, Bandung

Wursanto, IG, 2008, Manajemen Kepegawaian I,cetakan ketiga, Penerbit : Kanisius, Yogyakarta

Yuniarsih Tjutju, dan Suwatno, 2008, Manajemen Sumber Daya Manusia, cetakan pertama, Penebit: Alfabeta, Bandung 